DOI: https://doi.org/10.47405/mjssh.v6i1.624

\begin{tabular}{|c|c|}
\hline 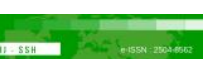 & Malaysian Journal of Social Sciences and Humanities (MJSSH) \\
\hline Malaysian Journal of & Volume 6, Issue 1, January 2021 \\
\hline (MJ-SSH) & e-ISSN : 2504-8562 \\
\hline & $\begin{array}{l}\text { Journal home page: } \\
\text { www.msocialsciences.com }\end{array}$ \\
\hline
\end{tabular}

\title{
The Influence of Job Motivation on Job Satisfaction: A Case Study of Polytechnic Academic Staff
}

\author{
Muhamad Saufiyudin Omar'1, Illyana Binti Mohd Idrus², ${ }^{2}$ Nor Ashikin Jamal' \\ ${ }^{1}$ Department of Tourism \& Hospitality, Politeknik Tuanku Syed Sirajuddin, Pauh Putra, 02600 Arau, Perlis, \\ Malaysia \\ ${ }^{2}$ Department of Tourism \& Hospitality, Politeknik Sultan Idris Shah, Sungai Lang, 45100 Sabak Bernam, \\ Selangor, Malaysia
}

Correspondence: Muhamad Saufiyudin Omar (saufiyudin@yahoo.com)

\begin{abstract}
Job motivation plays a vital role in determining job satisfaction levels. In the Malaysian Polytechnic context, limited studies have investigated the influence of job motivation on job satisfaction among academic staff. Therefore, this study aims is to examine the influence of job motivation on job satisfaction among polytechnic academic staff. This study employs quantitative research and single-cross sectional study. The data is gathered using the survey method. The result of multiple regression analysis shows that job motivation significantly and positively influences job satisfaction. More specifically, intrinsic and extrinsic motivation show a significant and positive influence on job satisfaction. It implies that improving job motivation in terms of intrinsic and extrinsic motivation is critically important to increase job satisfaction among polytechnic academic staff. Therefore, this study will contribute to polytechnic management as an indicator in the decision-making process to achieve the desired goals in the future.
\end{abstract}

Keywords: extrinsic motivation, intrinsic motivation, job satisfaction, Polytechnic Malaysia

\section{Introduction}

Many previous studies have identified that job satisfaction contributes to the organisation's effectiveness and efficiency. In the higher education context, academic staff plays a significant role in a university to achieve the university's objectives and performance (Yee, 2018). Moreover, academic staff also determines the students' success (de Lourdes Machado, Soares, Brites, Ferreira \& Gouveia, 2011). Therefore, understanding job satisfaction among academic staff is crucial and necessary for the university because it leads to their performance (Yee, 2018). One of the factors determining job satisfaction among academic staff is job motivation. Job motivation is crucial for the academic staff to determine their satisfaction, performance, students' achievement, and consequently, to improve the university's quality (de Lourdes Machado et al., 2011).

Herzberg's Two-Factor Theory is the most common motivation theory to measure job motivation (Mehrad, 2020). Herzberg (1987) introduced this theory by stating that some job factors result in satisfaction while other job factors prevent dissatisfaction. Besides, Herzberg (1987) has also classified these job factors into two categories, which are motivational factors and hygiene factors. Motivational 
factors refer to achievement, recognition, the work itself, responsibility, advancement, and personal growth. On the other hand, hygiene factors refer to company policy and administration, supervision, salary, interpersonal relationship, and working condition (Herzberg, 1987).

In this light, polytechnic academic staff may gain higher job satisfaction if they are happier with their work. However, most of the academic staff carry heavy workloads. They are not only educating students but also carrying out various management tasks that may lead to dissatisfaction (Omar, Rafie \& Selo, 2020). Besides, academic staff also needs to multitask, juggling academic and non-academic tasks to ensure the organisation runs smoothly (Omar, Salleh \& Aziz, 2020). According to Ridzuan, Baharudin, Ismail, Arham, Nazri and Rahman (2018), academic staff who constantly feels unpleasant and unsatisfied with the work will influence their work's execution and nature. Furthermore, employees may be satisfied with one or some of the job responsibilities but dissatisfied with other tasks at hand (Kalleberg, 1977). Hence, a study on factors influencing job motivation on job satisfaction is important among polytechnic academic staff to ensure their job motivation and job satisfaction levels are always at par; thus, ensuring the organisation's operation runs smoothly.

Many research has studied the influence of job motivation on job satisfaction globally (de Lourdes Machado et al., 2011; de Lourdes Machado-Taylor, Soares, Ferreira, Farhangmehr, Gouveia \& Peterson, 2016). However, minimal studies have focused on the influence of job motivation on job satisfaction in the Malaysian polytechnic academic staff context (Ali, 2016). Therefore, this study aims to examine the influence of job motivation, including intrinsic and extrinsic motivation, on job satisfaction of polytechnic academic staff, especially in the Department of Tourism and Hospitality. This study is significant to improve job satisfaction among academic staff and to enrich the body of knowledge in that particular area. Head of Departments (HoDs) and management team can also use it as a guideline to enhance staff satisfaction, especially in the Department of Tourism and Hospitality context.

\section{Literature Review}

\section{Job Motivation}

Motivation can be defined as the process of initiating human and individual activities, directed at attaining certain goals to fulfil some needs (Grujičić, Jovičić-Bata \& Novaković, 2018). Staff motivation is closely associated with the working process and represents an important factor in job satisfaction (Viseu, de Jesus, Rus \& Canavarro, 2016). In the higher education context, academic staff motivation plays a vital role in contributing to positive outcomes in the institutions' quality and students' learning. The university's success relies on the academic workforce (Stankovska, Angelkoska, Osmani \& Grncarovska, 2017). Usually, an individual who has job motivation will further maximise his or her performance, positive results, and minimise negative results, making him or her satisfied with his or her job (Wae-esor, Bakar \& Hee, 2016).

A study by Dalal, Baysinger, Brummel and Le-Breton (2012) found that job motivation is the most important indicator of an individual's job satisfaction. Tentama, Subardjo and Dewi (2020) affirmed that job motivation is one of the factors influencing job satisfaction. In the case of academic staff, both intrinsic and extrinsic factors affect their satisfaction (Stankovska et al., 2017). Further studies suggested that academic staff emphasise more on intrinsic satisfaction (Place, 1997), but other studies suggested mixed findings of intrinsic and extrinsic satisfiers are the best predictors of academic staff job satisfaction (Herzberg, 1987; Bentley et al., 2013). Their intrinsic satisfaction comes from teaching activities and responsibility. At the same time, extrinsic factors have been associated with academic staff job satisfaction, including salary, perceived support from boss and co-workers, and institutional resources availability. 


\section{Job Satisfaction}

Job satisfaction is defined as an affective variable resulting from evaluating an individual's work experience (Yuen, Loh, Zhou \& Wong, 2018). In other words, job satisfaction is the degree or level to which people like their job (Spector, 2008). The theory of equity can explain job satisfaction. Job satisfaction can come naturally by letting employees be self-directed (Shmailan, 2016). Usually, satisfied employees tend to be high-performing and highly committed to the organisation. Hence, a successful organisation must ensure a good relationship between employees and employer (Shmailan, 2016). Besides, the employer's unfair assessment in job assignments, promotions, salaries, and evaluation reports, compared to other colleagues, will adversely affect the employee job satisfaction (Torlak \& Kuzey, 2019). Therefore, the employer must ensure that all assessments are evaluated fairly to prevent employees from feeling dissatisfied with the organisation. Employees usually evaluate their job, either favourable or unfavourable, and whether the job conditions meet their expectations (Torlak \& Kuzey, 2019). It is because highly satisfied employees will outperform their dissatisfied colleagues (Yuen et al., 2018). Many scholars stated that satisfied employees tend to be present at work (i.e., low absences), make fewer mistakes (i.e., quality), more productive, and have stronger intentions to stay in the organisation (Sánchez-Beaskoetxea \& Coca García, 2015).

\section{Conceptual Framework and Hypothesis}

Based on the literature reviewed above, the conceptual frameworks for this study as below:

Figure 1: Conceptual Framework

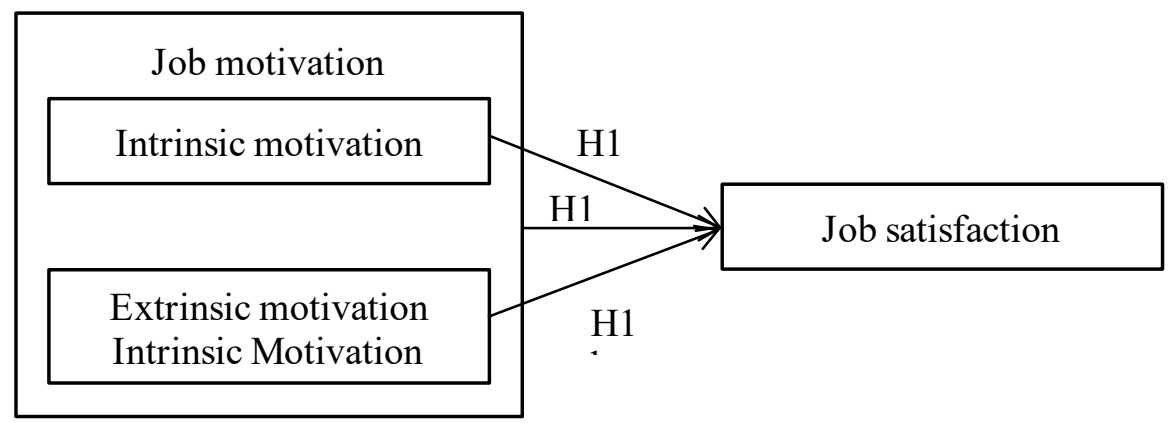

Based on the conceptual framework above, three hypotheses were developed:

Hypothesis 1: Job motivation influence job satisfaction.

Hypothesis 1a: Intrinsic motivation influence job satisfaction.

Hypothesis 1b: Extrinsic motivation influence job satisfaction.

\section{Methodology}

The current study employed a quantitative study and survey method. The unit analysis was the academic staff working at the Department of Tourism and Hospitality at four Malaysian polytechnics, which are Politeknik Tuanku Syed Sirajuddin (PTSS), Politeknik Sultan Idris Shah, Politeknik Merlimau Melaka (PMM), and Politeknik METrO Kuantan (PMKu). Based on Krejcie and Morgan (1970) table, the minimum number of samples required for a data collection is 108 respondents. The total population of the department at these four polytechnics was 169 .

This study used a questionnaire to measure all variables. The questionnaire was divided into four sections: Section A is on job satisfaction with 18 items adapted from Brayfield and Rothe(1951). Section $\mathrm{B}$ and $\mathrm{C}$ are on job motivation, divided into intrinsic and extrinsic motivation, with 71 items adapted 
DOI: https://doi.org/10.47405/mjssh.v6i1.624

from Dunnette, Campbell and Hakel (1967), Smerek and Peterson (2007), and Tech-Hong and Waheed (2011). Finally, Section D with seven items on the respondents' demographic profile.

Some modifications were made to the questionnaire to make it suitable for the current study. Then, the study employed the back-translation method introduced by Brislin (1970). The questionnaire was originally in the English version, which was then translated into Bahasa Malaysia, and later retranslated into English again to ensure its accuracy. Besides, this study also employed a five-point Likert scale, ranging from ' 1 -strongly disagree' to ' 5 -strongly agree' to measure all variables.

Printed questionnaires were used to collect the data. The researcher started the data collection with a letter informing the respondents concerning the study aims and explaining that the data gathered will be treated as confidential. Besides, the letter also stated that it would take approximately 20 minutes to complete the questionnaire. The questionnaire was self-administered, and the respondents' involvement was voluntary.

Next, all collected questionnaires were analysed using the Statistical Package for the Social Sciences (SPSS), version 22.0. The analysis involved descriptive analysis, mean and standard deviation, and inferential analysis, such as reliability test, correlation analysis, and multiple regression analysis. This study used Cronbach's alpha to check the reliability of the instruments. Based on the result of Cronbach's alpha, the value showed that all variables were more than 0.70 , indicating all items were reliable and well accepted for the study analysis.

\section{Result}

\section{Respondents Demographic}

Out of 169 samples, only 130 responded on the survey and gave a response rate of $77 \%$. The results showed that more female employees $(74.6 \%)$ answered the questionnaires compared to male $(25.4 \%)$. Mostly, the respondents aged between 31-40 years old (69.2\%) are the highest in answering the questionnaires, followed by 41-50 years old (25.4\%) and the lowest were between 51-60 years old $(0.8 \%)$. The respondents consist of Malays $(99.2 \%)$ and other race $0.8 \%$. In terms of service, most of the respondents have been in service between $11-15$ years (44.6\%), followed by $6-10$ years $(32.3 \%)$ and 15 years and above (13.8\%). In this study, employees from PTSS (39 employees) and PSIS (39 employees) are the highest respondents, followed by PMM with 36 employees $(27.7 \%)$ and lastly PMKu with 16 employees (12.3\%). Table 1 provides the demographic profile of the respondents.

Table 1: Demographic profile of respondents

\begin{tabular}{llll}
\hline Demographic variables & Category & Frequency & Percentage (\%) \\
\hline Gender & Male & 33 & 25.4 \\
Age & Female & 97 & 74.6 \\
& $21-30$ years old & 6 & 4.6 \\
& $31-40$ years old & 90 & 69.2 \\
Race & $41-50$ years old & 33 & 25.4 \\
& $51-60$ years old & 1 & .8 \\
Job Tenure & Malay & 129 & 99.2 \\
& Others & 1 & .8 \\
& $1-5$ years & 12 & 9.2 \\
Polytechnic & 6-10 years & 42 & 32.3 \\
& 11-15 years & 58 & 44.6 \\
& 15 years and above & 18 & 13.8 \\
& PTSS & 39 & 30.0 \\
& PSIS & 39 & 30.0 \\
& PMKu & 16 & 12.3
\end{tabular}




\section{Reliability}

Based on the finding obtained, the Cronbach's alpha coefficient of intrinsic motivation, extrinsic motivation and job satisfaction were above 0.70 which were indicated reliable. Table 2 showed the result of reliability of the study.

Table 2: Reliability result of the study

\begin{tabular}{ll}
\hline Variables & Cronbach's alpha value \\
\hline Intrinsic motivation & 0.908 \\
Extrinsic motivation & 0.936 \\
Motivation & 0.955 \\
Job satisfaction & 0.901 \\
\hline
\end{tabular}

\section{Simple Linear Regression Analysis of Job Motivation and Job Satisfaction}

The simple regression analysis was used to analyse the influence between job motivation and job satisfaction. Based on the result in Table 3 indicates that $\mathrm{R}^{2}=0.439$, which means that job satisfaction explain $43.9 \%$ of the variance in the employee performance with $\mathrm{F}=100.260, p=0.000$. The remaining of $56.1 \%$ was explained by the other factors. In this case, job motivation contributes significantly and positively towards the prediction of job satisfaction with the beta values of 0.663 . Hence, Hypothesis 1 is supported and showing that job motivation significantly and positively influenced job satisfaction in the context of Polytechnic employees.

Table 3: Simple liner regression analysis

\begin{tabular}{llllll}
\hline Model & B & SE B & $\boldsymbol{\beta}$ & t & Sig. \\
\hline Constant & .754 & .310 & & 2.437 & .016 \\
Motivation & .806 & .080 & .663 & 10.013 & .000 \\
\hline
\end{tabular}

Note: $\mathrm{R}^{2}=0.439 \mathrm{p}<0.00$.

\section{Multiple regression analysis of intrinsic motivation, extrinsic motivation and job satisfaction}

The multiple regression analysis was used to analyse the influence between intrinsic motivation, extrinsic motivation and job satisfaction. Based on the result in Table 4 indicates that $\mathrm{R}^{2}=0.464$, which means that job satisfaction explain $46.4 \%$ of the variance in the employee performance with $\mathrm{F}=100.260, p=$ 0.000 . The remaining of $53.6 \%$ was explained by the other factors. In this case, intrinsic motivation and extrinsic motivation contributes significantly and positively towards the prediction of job satisfaction with the beta values of 0.178 and 0.552 respectively. Hence, Hypothesis 1a is supported and showing that intrinsic motivation significantly and positively influenced job satisfaction and hypothesis $1 \mathrm{~b}$ is supported and showing that extrinsic motivation significantly and positively influenced job satisfaction in the context of Polytechnic staff.

Table 4: Multiple regression analysis

\begin{tabular}{llllll}
\hline Model & B & SE B & Beta & t & Sig. \\
\hline (Constant) & .797 & .309 & & 2.578 & .011 \\
Intrinsic motivation & .213 & .105 & .178 & 2.030 & .044 \\
Extrinsic motivation & .580 & .092 & .552 & 6.279 & .000 \\
\hline
\end{tabular}

Note: $\mathrm{R}^{2}=0.464 \mathrm{p}<0.00$. 


\section{Discussion}

The purpose of this study was to examine the influence between job motivation that including intrinsic motivation and extrinsic motivation toward job satisfaction among the staff of Department of Tourism and Hospitality at four polytechnic that offered this courses. This objective has been achieved and the results indicated that job motivation was significant and positively influences job satisfaction. These results also included the intrinsic motivation and extrinsic motivation that indicated significant and positive influence on job satisfaction. This result suggested that when academic staff are fully motivated in term of intrinsic and extrinsic motivation, they will be more satisfied with their jobs. This is in line with the study of Sari (2017) that also found that work motivation significant and positively influence job satisfaction. This is probably because most of the academic staff satisfied with their organization in term of recognizes their achievements, their job gives the feeling of accomplishment and they enjoy the type of work they do. This is consistent with de Lourdes Machado et al. (2011) that mentioned motivation is based on human needs which generate within an individual.

Moreover, the finding also showed that extrinsic motivation is the major influence on job satisfaction among the academic staff compare to intrinsic motivation. This is consistent with the finding of Bentley et al. (2013) that indicated extrinsic motivation are the best predictors of academic staff' job satisfaction. This showed that most of the academic staff in Polytechnic well satisfied with the element of company policy and administration, supervision, the working conditions, relationships with co-workers and job security as well as job status. Therefore, this suggested that the management need to emphasis more on extrinsic motivation element compare to intrinsic motivation in the context of academic staff of the polytechnic.

\section{Conclusion}

In sum, the current study found that job motivation was significantly and positively influence job satisfaction among Department of Tourism and Hospitality staff at these four polytechnics. In addition, the results also showed that intrinsic motivation and extrinsic motivation were significantly and positively influence job satisfaction. This implies that enhancing job motivation in term of intrinsic motivation and extrinsic motivation were critically important to improve the level of job satisfaction among the staff. Consequently, it will also improve the organization in a better way.

This study encounters few limitations. First limitation was the variables used. Since the result of the study showed that there are other factors that influenced staff job satisfaction, perhaps future studies could include other element to measure polytechnics staff job satisfaction. Secondly, this study focuses staff in Department of Tourism and Hospitality only; perhaps in the future it could include other departments such as Electrical Engineering Department, Mechanical Engineering Department, Department of Information Technology and Communication and Commerce Department.

\section{References}

Ali, W. (2016). Understanding the concept of job satisfaction, measurements, theories and its significance in the recent organizational environment: A theoretical framework. Archives of Business Research, 4(1), 100-111.

Bentley, P. J., Coates, H., Dobson, I. R., Goedegebuure, L., \& Meek, V. L. (2013). Factors associated with job satisfaction amongst Australian university academics and future workforce implications. In: Bentley, P. J., Coates, H., Dobson, I. R., Goedegebuure, L., \& Meek, V. L. (eds). Job Satisfaction around the Academic World. The Changing Academy - The Changing Academic Profession in International Comparative Perspective, 7, 29-53. Springer, Dordrecht.

Brayfield, A. H., \& Rothe, H. F. (1951). An index of job satisfaction. Journal of Applied Psychology, 35(5), 307-311. 
Brislin, R. W. (1970). Back-translation for cross-cultural research. Journal of Cross-Cultural Psychology, 1(3), 185-216.

Dalal, R. S., Baysinger, M., Brummel, B. J., \& LeBreton, J. M. (2012). The relative importance of employee engagement, other job attitudes, and trait affect as predictors of job performance. Journal of Applied Social Psychology, 42, 295-325.

de Lourdes Machado-Taylor, M., Meira Soares, V., Brites, R., Brites Ferreira, J., Farhangmehr, M., Gouveia, O. M. R., \& Peterson, M. (2016). Academic job satisfaction and motivation: findings from a nationwide study in Portuguese higher education. Studies in Higher Education, 41(3), 541559.

de Lourdes Machadoa, M., Soaresb, V. M., Britesc, R., Ferreirad, J. B., Gouveiae, O. M. R. (2011). A look to academics job satisfaction and motivation in Portuguese higher education institutions. Procedia - Social and Behavioral Sciences, 29, 1715-1724.

Dunnette, M. D., Campbell, J. P., \& Hakel, M. D. (1967). Factors contributing to job satisfaction and job dissatisfaction in six occupational groups. Organizational Behavior and Human Performance, 2(2), 143-174.

Grujičić, M., Jovičić-Bata, J., \& Novaković, B. (2018). Motivation and job satisfaction of healthcare professionals in urban and rural areas in the autonomous province of Vojvodina, Serbia. Medicinski Pregled, 71(1-2), 33-41.

Hee, O. C., Ong, S. H., Ping, L. L., Kowang, T. O., \& Fei, G. C. (2019). Factors influencing job satisfaction in the Higher Learning Institutions in Malaysia. International Journal of Academic Research in Business and Social Sciences, 9(2), 10-20.

Herzberg, F. (1987). One more time: how do you motivate employees?. Harvard business review, 65(5).

Kalleberg, A. L. (1977). Work values and job rewards: A theory of job satisfaction. American Sociological Review, 124-143.

Krejcie, R. V., \& Morgan, D. W. (1970). Determining sample size for research activities. Educational and Psychological Measurement, 30(3), 607-610.

Machado-Taylor, M. D. L., Soares, V. M., Ferreira, J. B., \& Gouveia, O. M. R. (2011). What factors of satisfaction and motivation are affecting the development of the academic career in Portuguese higher education institutions?. Revista de Administração Pública, 45(1), 33-44.

Mehrad, A. (2020). Evaluation of academic staff job satisfaction at Malaysian universities in the context of Herzberg's Motivation-Hygiene Theory. Journal of Social Science Research, 15, 157-166.

Omar, M. S., Aziz, S. F. A., \& Salleh, N. M. (2020). Factors affecting job satisfaction among academic employees in polytechnic. Malaysian Journal of Social Sciences and Humanities, 5(11), 209-216.

Omar, M. S., Rafie, N., \& Selo, S. A. (2020). Job Satisfaction Influence Job Performance among Polytechnic Employees. International Journal of Modern Trends in Social Sciences, 3(14), 3946.

Place, A. W. (1997): Career choice of education: Holland type, diversity and self-efficacy. Journal for a just and Curing Education, 3, 203-214.

Ridzuan, A. R., Baharudin, N. 'Aqilah A., Ismail, S., Arham, A. F., Nazri, N. M., \& Rahman, M. F. A. (2018). Measuring the Factors of Employees' Job Satisfaction among Lecturers in UiTM Melaka. International Journal of Academic Research in Business and Social Sciences, 8(10), 899-914.

Sánchez-Beaskoetxea, J., \& Coca García, C. (2015). Media image of seafarers in the Spanish printed press. Maritime Policy \& Management, 42(2), 97-110.

Sari, E. T. (2017). Motivation and satisfaction towards employees' loyalty to achieve company's advantage. Jurnal Manajemen Bisnis dan Inovasi, 4(1), 69-81.

Shmailan, B., \& Abdulwahab, S. (2016). The relationship between job satisfaction, job performance and employee engagement: An explorative study. Issues in Business Management and Economics, 4 (1), 1-8.

Smerek, R. E., \& Peterson, M. (2007). Examining Herzberg's theory: Improving job satisfaction among non-academic employees at a university. Research in Higher Education, 48(2), 229-250.

Stankovska, G., Angelkoska, S., Osmani, F., \& Grncarovska, S. P. (2017). Job Motivation and Job Satisfaction among Academic Staff in Higher Education. Bulgarian Comparative Education Society, 15, 159-166.

Teck-Hong, T., \& Waheed, A. (2011). Herzberg's Motivation-Hygiene Theory and job satisfaction in the Malaysian retail sector: The mediating effect of love of money. Asian Academy of Management Journal, 16(1), 73-94. 
Tentama, F., Subardjo, Dewi, L. (2020). The correlation between work motivation and job satisfaction of the academic staffs. International Journal of Scientific \& Technology Research, 9(2), 22952297.

Torlak, N. G., \& Kuzey, C. (2019). Leadership, job satisfaction and performance links in private education institutes of Pakistan. International Journal of Productivity and Performance Management, 68(2), 276-295.

Viseu, J., de Jesus, S.N., Rus, C., \& Canavarro, J.M. (2016). Teacher motivation, work satisfaction, and positive psychological capital: A literature review. Electronic Journal of Research in Educational Psychology, 14(2), 439-461.

Wae-esor, E., Bakar, A. B. A., \& Hee, H. C. (2016). The relationship between work motivation and job satisfaction of muslim public health employees in Pattani Province, Thailand. Journal of Global Business and Social Entrepreneurship (GBSE), 2(1), 162-171.

Yee, L. C. (2018). An Analysis on the Relationship between Job Satisfaction and Work Performance among Academic Staff in Malaysian Private Universities. Journal of Arts \& Social Sciences, 1(2), 64-73.

Yuen, K. F., Loh, H. S., Zhou, Q., \& Wong, Y. D. (2018). Determinants of job satisfaction and performance of seafarers. Transportation Research Part A: Policy and Practice, 110, 1-12. 